
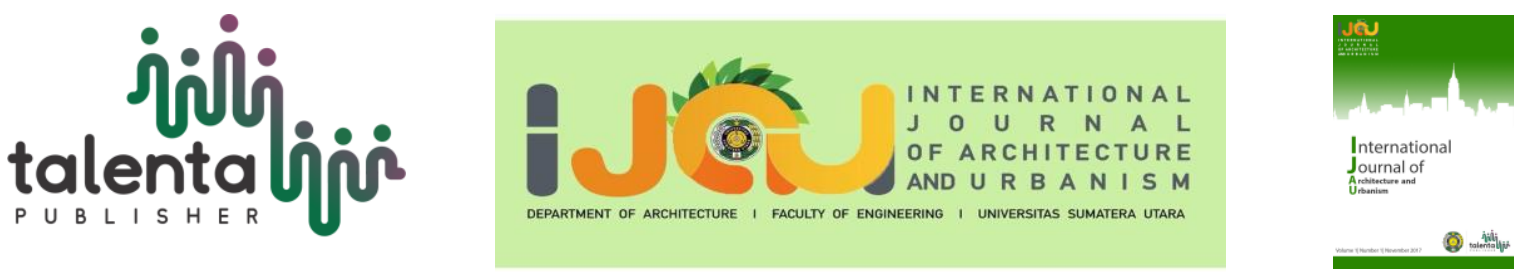

\title{
The Use of Metaphor in Designing Ocean World Aquarium
}

\author{
Harisdani, D. D. ${ }^{{ }^{*}}$, Deo Riza Sativa ${ }^{1}$ \\ ${ }^{I}$ Departement of Architecture, Faculty of Engineering, Universitas Sumatra Utara, Medan, Indonesia
}

\begin{abstract}
Ocean World Aquarium design is a design for developing Cermin Beach Theme Park is located in Serdang Berdagai Regency, North Sumatera. This design depicts the sea and coastal life, such as the beach and the Mangrove forest. The application of metaphor in this architecture becomes one of the sell values of this building. The shape of coastal animals such as Crab is chosen as a metaphor for the building design. This Ocean Aquarium design is expected to benefit the community by becoming a recreational and educational place as well, and able to be a creative and educational vehicle in this Theme Park development tour.
\end{abstract}

Keyword: aquarium, Cermin Beach, marine, metaphor

Received date month year.|Revised 4 October 2020 | Accepted 18 November 2020

\section{Introduction}

Cermin Beach area is the leading choice of marine tourism people of Serdang Bedagai and several other areas nearby, due to its strategic location and easy access to the area. The theme park on the Cermin Beach has long been known by the public as a tourist attraction and has the potential to be developed into a national and even international tourist attraction. Tourist visits each year experience $10 \%$ per year based on the data masterplan of Cermin Beach tourism in Kab. Deli Serdang, Tourism Office Level I SUMUT [1].

The theme park in Cermin Beach is still less iconic in the area due to the lack of attraction to the architecture of the building from the attraction.

So it is necessary to develop the theme park tourism with the addition of a tourist attraction called Ocean World Aquarium to display the natural richness of flora and fauna identical to the

\footnotetext{
*Corresponding author at:Department of Architecture, Faculty of Engineering, Universitas SumateraUtara, Jalan Perpustakaan Gedung J07,Medan 20155, Indonesia

E-mail address: devin.defriza@usu.ac.id
}

Copyright (c) 2020 Published by Talenta Publisher, 
marine area of Cermin Beach, which includes Mangrove, Beach, and Sea as three main objects in the design of this building.

\section{Literature Review}

The aquarium is a small piece of water environmental adaptation centered in the form of displays of glass or other see-through materials, imitating from nature both water conditions, display forms [2].

At first, the aquarium was just an artificial natural transfer or a display of the beauty of ornamental fish. Besides being a recreational facility for some people, the aquarium is also useful for psychiatric patients or those who experience psychiatric pressure or stress. Aquarium functions include receding, educational, psychic, creative arts, aesthetics, tourism [3].

Mangrove forests are forests that grow in river estuaries, tidal or seaside areas. Mangrove plants are unique because they combine plant features that live on land and in the sea [4]. The existence of mangroves can play a role in filtering and reducing the level of pollution in seawater, and economic benefits such as wood products and beneficial as a protector for the environment of land and ocean ecosystems [5].

Coastal ecosystems are defined as ecosystems that are a unit of components, both biotic and abiotic, that are around the coast and interact with each other, and influence each other, and the formation of energy flow [6]. In addition to forming energy, the interaction between the components also forms the abiotic structure and a material cycle [7].

Metaphor plays a central role in changing the architectural process. Metaphorical Understanding in Architecture is an allusion or expression of form, embodied in a building in the hope of eliciting a response from the person who enjoys or uses his work [8]. Metaphors in architecture are identified into three categories, namely.

Intangible Metaphor

Design refers to things that are abstract and unstoppable. Abstract metaphors can be seen in some of the works of Japanese architects, such as Kisho Kurokawa in his Nagoya City Art. This building puts forward elements of history and culture that are something of an abstract object that is not intangible (Figure 1). 


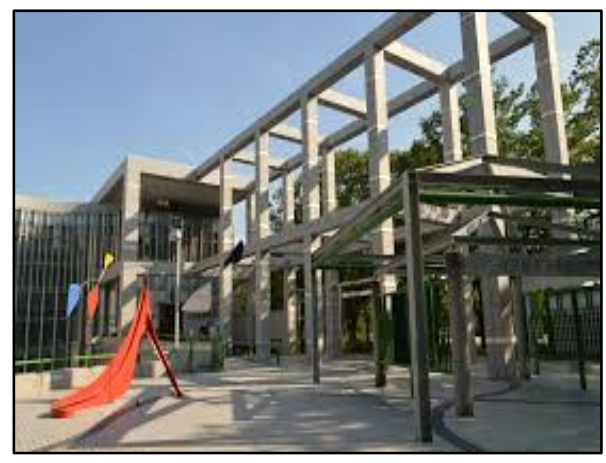

Figure 1 Nagoya City Art

Source: Google Image 2020

\section{Tangible Metaphor}

Architectural design that refers to tangibles and can be felt visually. Concrete Metaphor can be seen in Santiago Calatrava's TGV Station. The TGV station is an interpretation of the Metaphor of a bird (Figure 2).

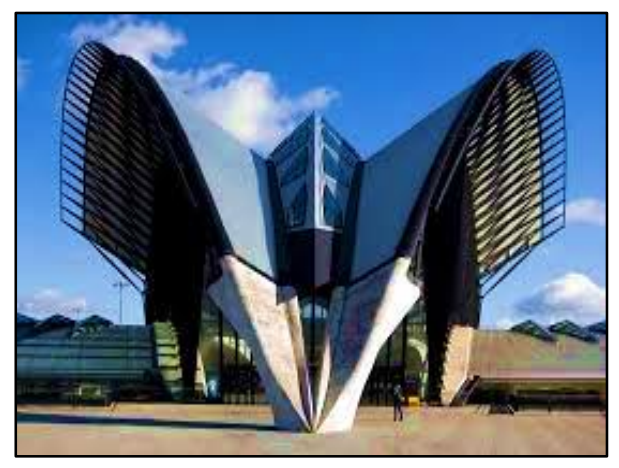

Figure 2 Stasiun TGV

Source: Google Image 2020

\section{Combination Metaphor}

An architectural design that has abstract and concrete Metaphors in it produces a form of application that does not directly display a shape but instead, there is a stage of transformation in it. The architectural design that uses this Metaphor is EX Plaza Indonesia by Budiman Hendropurnomo, making the kinetic style of an as its concept, which translates into a five-box time tile that tilts as an expression of the kinetic style of the car (Figure 3). 


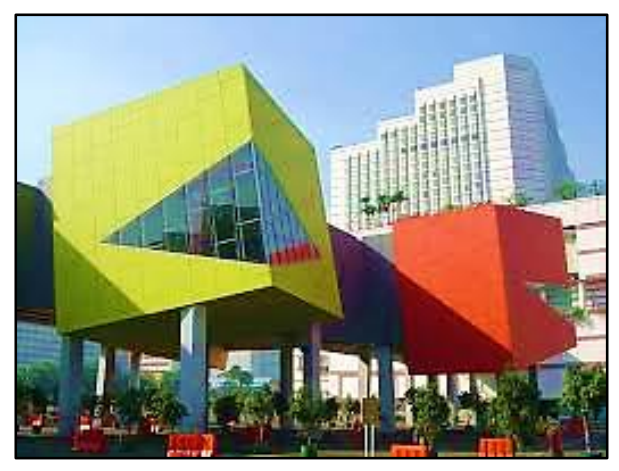

Figure 3 Ex Plaza Indonesia

Source: Google Image 2020

In the design of Ocean World Aquarium, using Tangible Metaphor (Concrete), where the design comes from the concept of the shape of marine animals on the beach such as shellfish, shrimp, etc. or the shape of waves that indicate the location and function of buildings related to underwater life. The shape of marine animals taken in the application of metaphors in the architecture is crab animals.

\section{Methodology}

\subsection{Methodology of Location Determination}

Based on Regional Regulation of Kab. Serdang Berdagai, number 9 of 2008, on the Management of Coastal Attractions, states that The Cermin Beach Area includes the development area of the tourist area. Based on the perda, this location is designated as the location of the Ocean World Aquarium building design project.

There are three alternative sites in determining the building's planning location, following its assessment table 1.

Table 1 Site Scoring Determination

\begin{tabular}{|c|c|c|c|c|c|c|c|}
\hline \multirow[t]{3}{*}{ No } & \multirow[t]{3}{*}{ Criteria } & \multicolumn{6}{|c|}{ Site Scoring Determination } \\
\hline & & \multicolumn{2}{|c|}{ Alternatif 1} & \multicolumn{2}{|c|}{ Alternatif 2} & \multicolumn{2}{|c|}{ Alternatif 3} \\
\hline & & Condition & Score & Condition & Score & Condition & Score \\
\hline 1) & $\begin{array}{l}\text { Accessibility } \\
\text { in reaching } \\
\text { the site }\end{array}$ & $\begin{array}{l}\text { The site is not } \\
\text { far from the } \\
\text { main road } \\
\text { junction from } \\
\text { the Medan } \\
\text { direction. }\end{array}$ & 4 & $\begin{array}{l}\text { The site is } \\
\text { right at the } \\
\text { main road } \\
\text { junction from } \\
\text { the Medan } \\
\text { direction. So } \\
\text { it was first } \\
\text { encountered } \\
\text { from the main } \\
\text { road } \\
\text { disbanding } \\
\text { other sites. }\end{array}$ & 5 & $\begin{array}{l}\text { The site is } \\
\text { quite far } \\
\text { from the } \\
\text { main road } \\
\text { junction } \\
\text { from the } \\
\begin{array}{l}\text { Medan } \\
\text { direction. }\end{array}\end{array}$ & 3 \\
\hline
\end{tabular}




\begin{tabular}{|c|c|c|c|c|c|c|c|}
\hline \multirow[t]{3}{*}{ No } & \multirow[t]{3}{*}{ Criteria } & \multicolumn{6}{|c|}{ Site Scoring Determination } \\
\hline & & \multicolumn{2}{|c|}{ Alternatif 1} & \multicolumn{2}{|c|}{ Alternatif 2} & \multicolumn{2}{|c|}{ Alternatif 3} \\
\hline & & Condition & Score & Condition & Score & Condition & Score \\
\hline 2) & $\begin{array}{c}\text { The situation } \\
\text { around the } \\
\text { site }\end{array}$ & $\begin{array}{l}\text { The site is near } \\
\text { the residential } \\
\text { area and right } \\
\text { next to the } \\
\text { beach tourist } \\
\text { area. }\end{array}$ & 4 & $\begin{array}{l}\text { The site is } \\
\text { right next to } \\
\text { the Theme } \\
\text { Park } \\
\text { attraction, } \\
\text { which is the } \\
\text { object of } \\
\text { development } \\
\text { on this project } \\
\text { and in support } \\
\text { of its hotels } \\
\text { and resorts. }\end{array}$ & 5 & $\begin{array}{l}\text { The site is } \\
\text { also next to } \\
\text { the } \\
\text { development } \\
\text { object. But } \\
\text { most sides of } \\
\text { the site still } \\
\text { face } \\
\text { mangrove } \\
\text { areas and } \\
\text { fish/shrimp } \\
\text { ponds. }\end{array}$ & 3 \\
\hline 3) & $\begin{array}{l}\text { Distance } \\
\text { from the } \\
\text { shoreline for } \\
\text { seawater } \\
\text { supply }\end{array}$ & $\begin{array}{l}\begin{array}{l}\text { Located at a } \\
\text { distance of } \\
\text { approximately }\end{array} \\
120 \text { meters } \\
\text { from the } \\
\text { shoreline. }\end{array}$ & 4 & $\begin{array}{l}\text { Located } \\
\text { approximately } \\
150 \text { meters } \\
\text { from the } \\
\text { shoreline. }\end{array}$ & 4 & $\begin{array}{l}\text { It is right on } \\
\text { the } \\
\text { shore.Hence, } \\
\text { it is easier to } \\
\text { access the } \\
\text { seawater } \\
\text { supply into } \\
\text { the building. }\end{array}$ & 5 \\
\hline 4) & Noise & $\begin{array}{l}\text { Not at the } \\
\text { crossroads but } \\
\text { right next to } \\
\text { the beach tour, } \\
\text { so the noise } \\
\text { still occurs. }\end{array}$ & 4 & $\begin{array}{l}\text { Located at the } \\
\text { main road } \\
\text { junction from } \\
\text { Medan } \\
\text { direction and } \\
\text { adjacent to } \\
\text { the Theme } \\
\text { park tour, the } \\
\text { noise level is } \\
\text { relatively } \\
\text { high. }\end{array}$ & 4 & $\begin{array}{l}\text { The noise is } \\
\text { relatively } \\
\text { low because } \\
\text { it is only } \\
\text { sourced from } \\
\text { the Theme } \\
\text { Park touron } \\
\text { the west side } \\
\text { of the site. }\end{array}$ & 5 \\
\hline
\end{tabular}

\begin{tabular}{llll} 
Total & 16 & 18 & 16 \\
\hline
\end{tabular}

Description:

$5=$ Very Good

$4=$ Good

$3=$ Enough

$2=$ Not Good Enough

$1=$ Not Good 
So with the Location Selection Table above then the site that is more potential to be used as a design site Ocean World Aquarium is a site that is in alternative 2 with the advantages that exist from the table selection criteria above.

\subsection{Design Method}

Design methods are an attempt to find the right physical components of a physical structure [9]. In the process of designing the Ocean World Aquarium, it takes data for useful information in the first step of the design. The required data can be classified into two categories. Primary data is data collected directly about site location, existing environment, site limits, views, climatic conditions, existing utilities, and more. Meanwhile, secondary data is data obtained through library reviews, analysis, and comparative studies of similar projects [10].

This data is needed to create an ideal design for ocean world aquarium design. The data that has been obtained is then analyzed. From the data analyzed, metaphorical and visual ideas are then moved into building standards to form designs that provide value, effectiveness, and efficiency [11].

\section{Result and Discussion}

This building will serve as a marine tourist attraction located in Cermin Beach. To display the function of the building, a metaphorical theme is chosen as the basis for the theme of mass formation. In this case, The shape taken symbolizes the shape is Crab. This form was taken because crabs lived in coastal waters and mangroves, which later also became the central concept of space design in this project. Crabs are also one of the livelihoods of local people for consumption and commercial needs. Mangroves, beaches, and the sea are the three main things that become the selling power of this building to attract tourists. These three things are also the central element of the design location, namely Cermin Beach. Architecture is a communication tool to provide the desired instructions to influence visitors or tourists. Models that rely on shape as character markers are one type of building that is can communicate [12].

\subsection{Design Location}

The location of this project is in the tourist area of Cermin Beach. Cermin Beach is located on the east coast of Sumatra island facing the Strait of Malacca. It is located $45 \mathrm{Km}$ from Medan city to Pematang Siantar (9 Km from Simpang Tiga Perbaungan) from Sei Rampah (capital of Serdang Bedagai Regency) $25 \mathrm{~km}$ away. Access to Cermin Beach is excellent. The road condition is quite broad and paved smoothly makes the trip to this tourist area feel comfortable (Figure 4). 


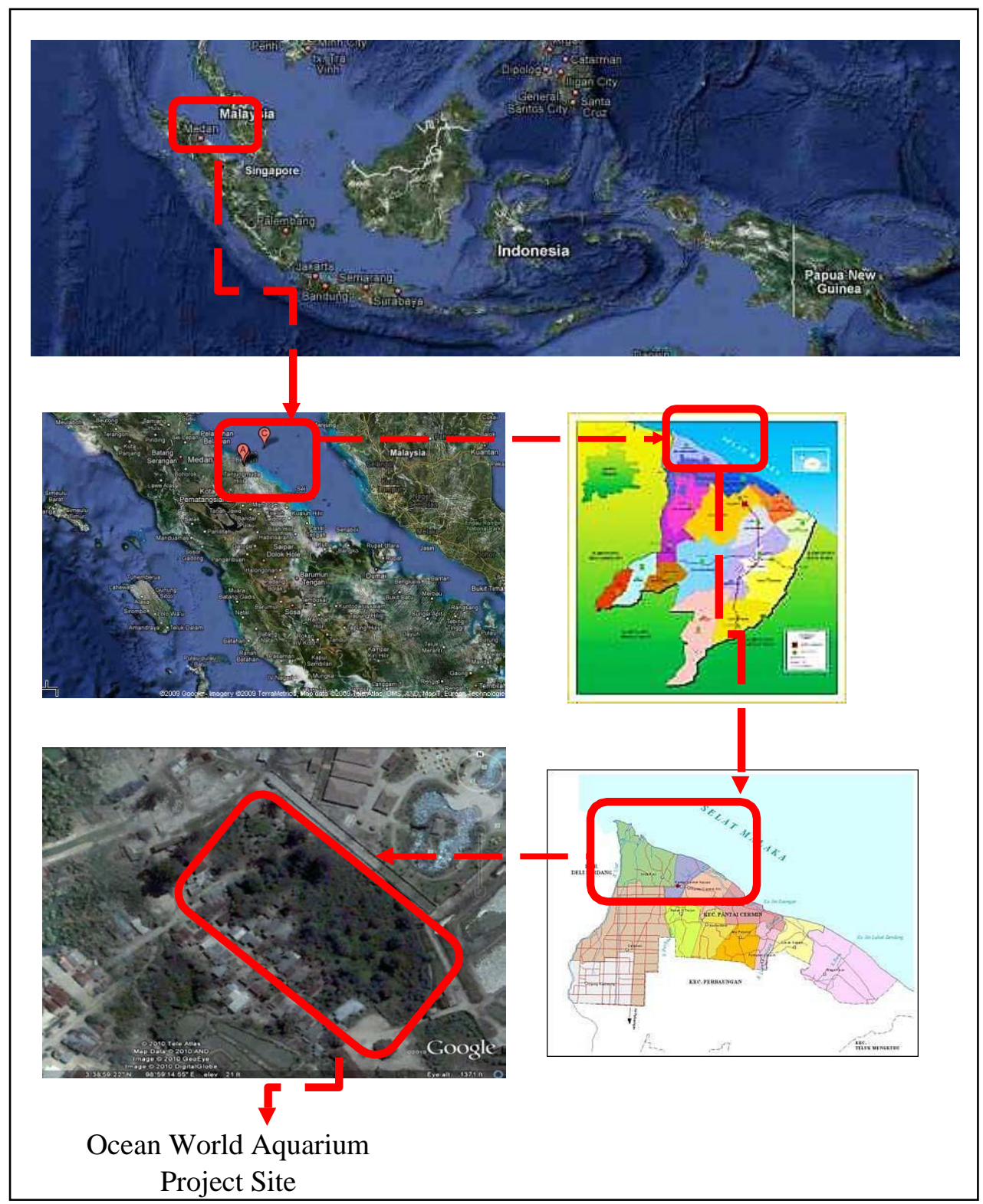

Figure 4 Design Location

Source: Google Earth 2020

In RUTRW (Rencana Umum Tata Ruang Wilayah Serdang Bedagai), location is in the area of Cermin Beach, entered into WP B (Development Area B) which is the Central Area of subdistrict government, services, trade, recreation, settlements, educational facilities, and public hospitals.

The function of the surrounding location is the majority as a recreational facility and residential area. Some areas also have mangroves and fish pond areas for the economic needs of the surrounding residents.

\subsection{Basic Building Concepts}

The rationale of the Ocean World Aquarium building is to realize a public facility that is Edutainment (Education and Entertainment), where this building in addition to being a family 
facility can also serve as an informal educational facility in the field of public knowledge about life in the sea and waters of Indonesia.

\subsection{Mass Concept}

This building will serve as a marine tourist attraction located in Cermin Beach. In this case, The shape taken is a metaphor for the shape of a crab. This form is taken because crabs are one of the income of the local population and are also identical to mangrove and coastal areas (Figure $5)$.

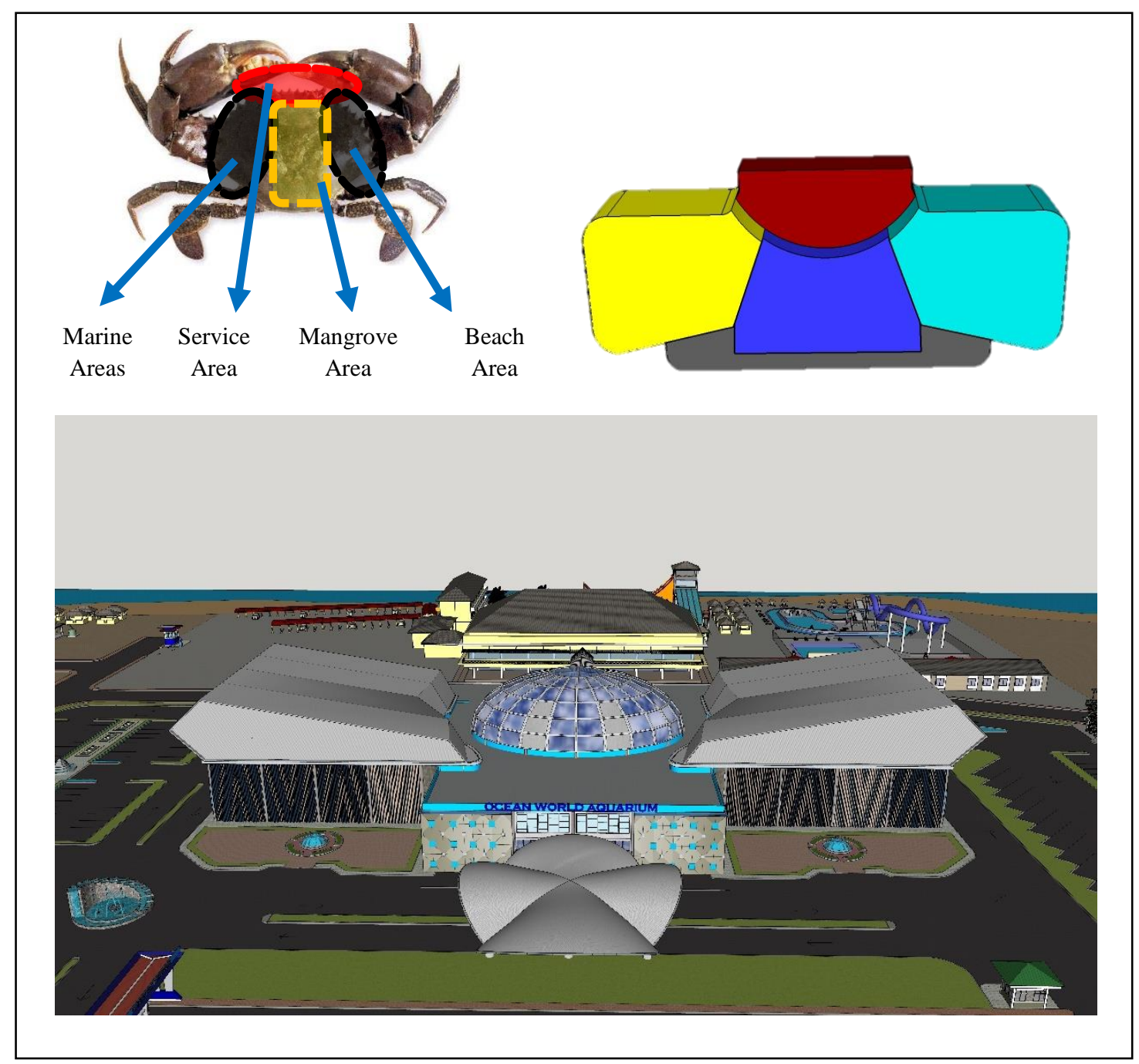

Figure 5 Mass Concept

\subsection{Facade Metaphorical Transformation}

To display the function of the building, a metaphorical theme is chosen as the basis for the theme of mass formation. In this case, the shape taken symbolizes the shape is Crab. This form was taken because crabs lived in coastal waters and mangroves, which later also became the central concept of space design in this project (Figure 6). 


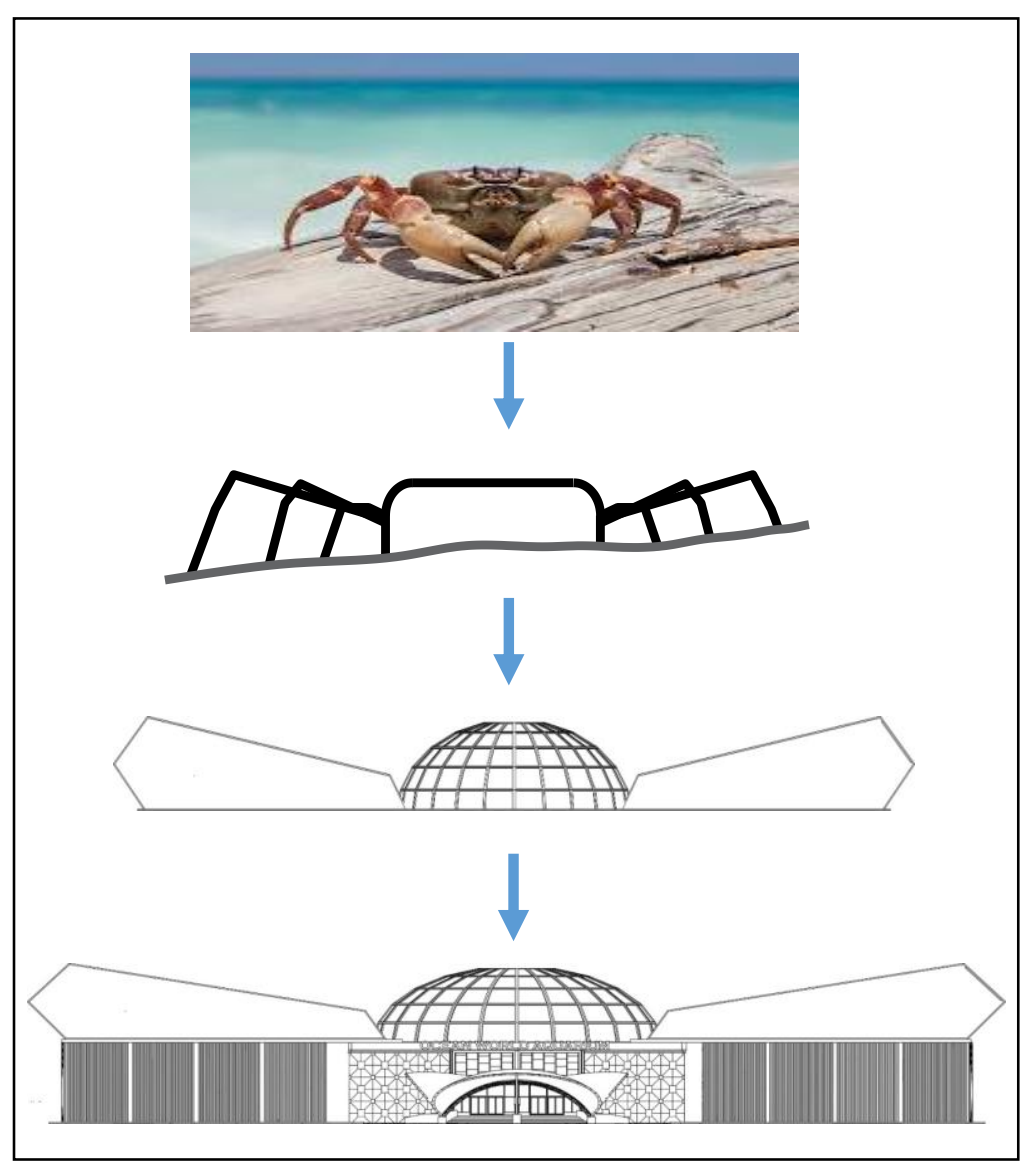

Figure 6 Concept of Mass Transformation

\subsection{Structure Concept}

The concept of the structure used in this building consists of the lower structure and the body/top. The following has been determined the concept of the structure chosen, namely:

\section{Bottom Structure/Foundation}

The foundation of the building is required a deep foundation due to the condition of the soil that is not dense that is in the sandy area [13]. This building is planned to use a bore pile foundation (Figure 7).

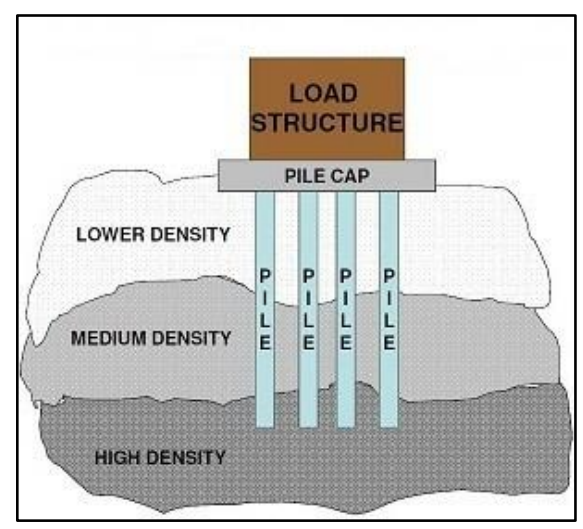

Figure 7 Bore Pile Foundation

Source: Google Image 2020 


\section{Upper Structure}

The selection of body structure based on consideration can meet the needs of building functions, the advantages of structures that are economical, earthquake resistant, and comfortable in their implementation, and can be applied to complete span buildings [14].

Based on the above criteria, the Ocean World Aquarium design project uses a truss/space frame structure system with steel construction (Figure 8).

The advantages of this structure are the easy implementation, earthquake resistance, economy, openings, and division of freer space because the walls are not just filled structures.

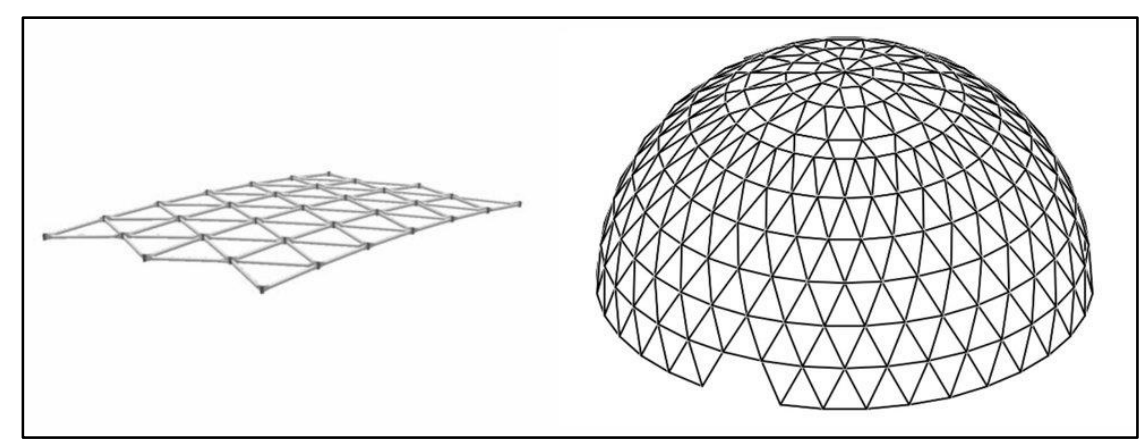

Figure 8 Space Frame

Source: Google Image 2020

\subsection{Utility Concept}

Clean Water

The source of clean water comes from the company runs provincial water: if it is damaged, the boreholes will be used as a backup water source (Figure 9) [15].

Dirty Water

The waste water distribution system can be divided into two: the weighing system (using a pump) and the gravitational system (using a unique piping shaft) (Figure 10) [16]. 


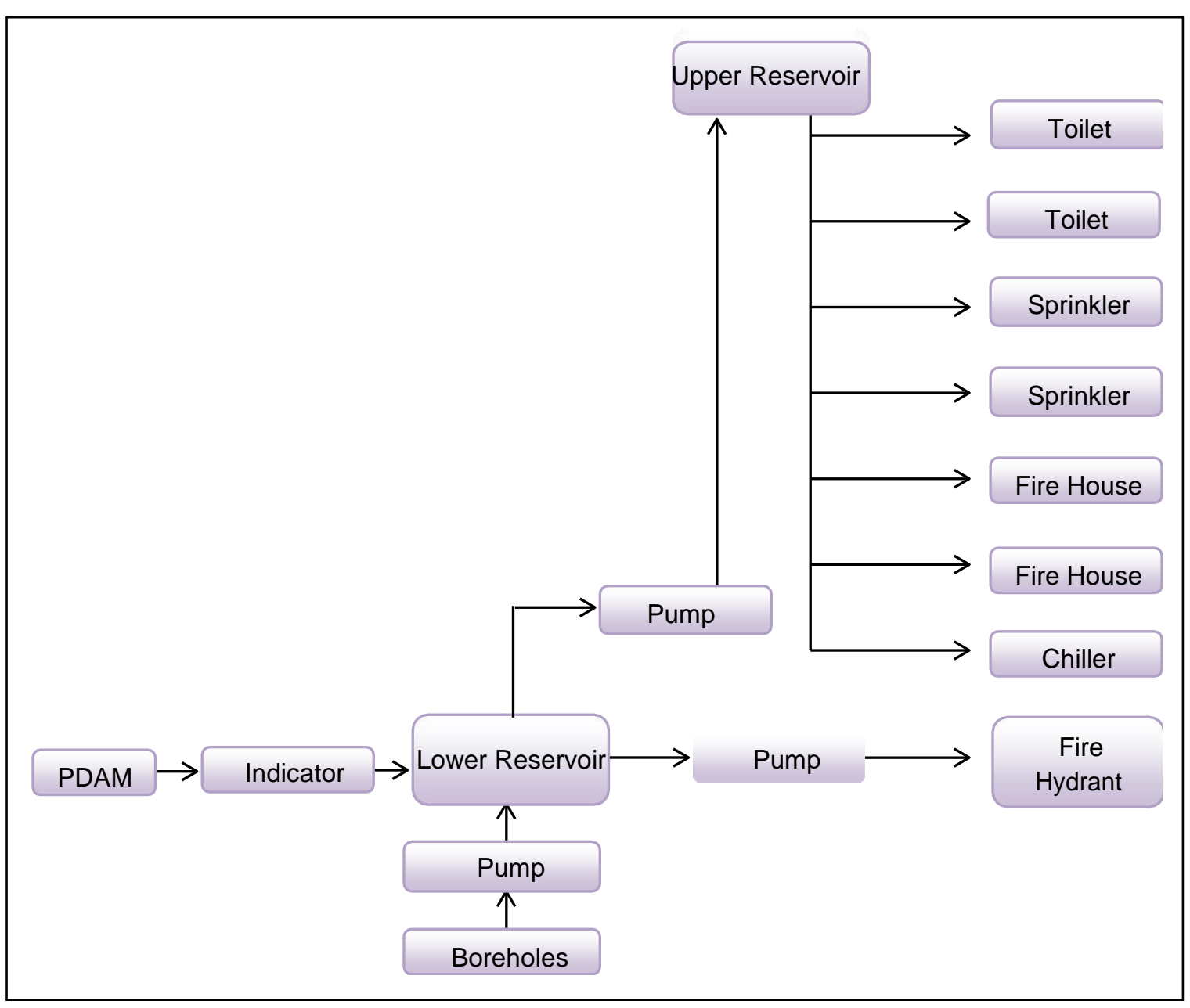

Figure 9 Clean Water Scheme

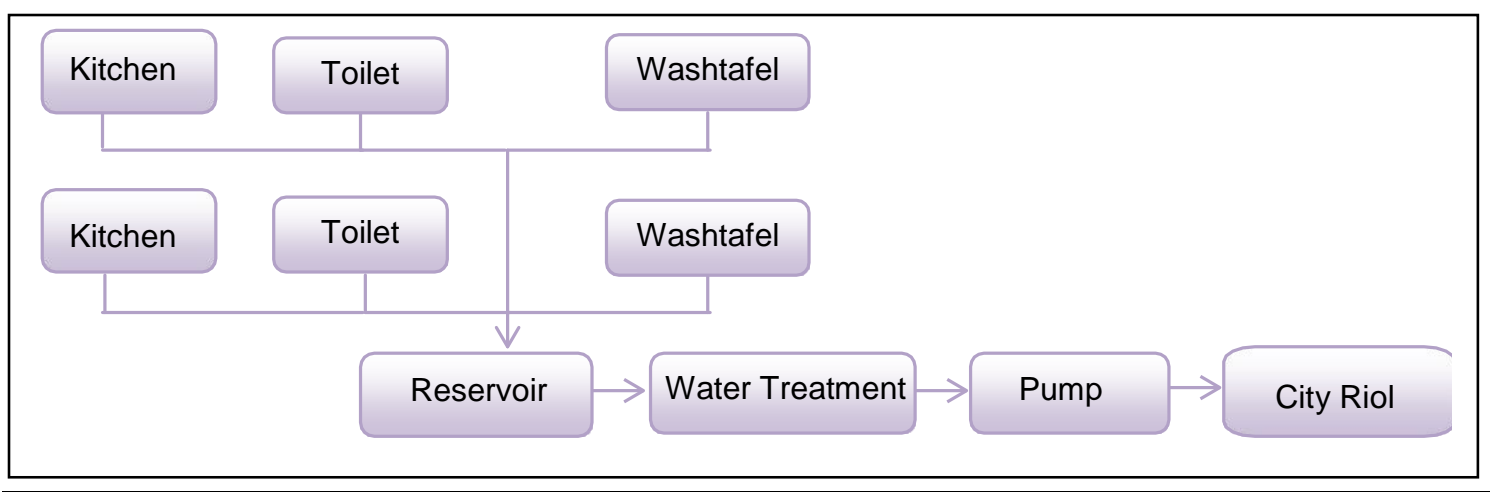

Figure 10 Dirty Water Scheme

\section{Conclusion}

Ocean World Aquarium is a recreational vehicle that aims to attract visitors, so it takes a unique shape as well. The shape of one of the coastal animals is crab into a metaphorical form that will be designed to resemble a building. The use of this theme is very closely related to the visuals be displayed in the building, given that the building is in a coastal area so that it will become iconic in this area with the shape of the building. 
In the design of Ocean World Aquarium, it is expected to be able to raise the potential of marine resources in Indonesia to be better, and provide good benefits for the community and be a creative and educational vehicle.

\section{REFERENCES}

[1] Pemerintahan Kab. Serdang Bedagai. Peraturan Daerah Kabupaten Serdang Bedagai Nomor 9 Tahun 2008 Tentang Pengelolaan Objek Wisata Pesisir Pantai Dan Sungai Di Kabupaten Serdang Bedagai, 2008.

[2] Rhyne, Andrew L., et al. "Expanding our understanding of the trade-in marine aquarium animals." PeerJ 5, 2017.

[3] Kuncoro, Eko Budi.Akuarium Laut. Penerbit Kanisius. Yogyakarta, 2005.

[4] Mulyadi, E., Hendriyanto, O., \& Fitriani, N. Konservasi hutan mangrove sebagai ekowisata. Jurnal Ilmiah Teknik Lingkungan, 2(1). 11-18, 2010.

[5] Kulkarni, Rasika, Deepti Deobagkar, and Smita Zinjarde. "Metals in mangrove ecosystems and associated biota: a global perspective." Ecotoxicology and environmental safety 153. 215-228, 2018.

[6] Baransano, Hengky K., and Jubhar C. Mangimbulude. "Eksploitasi dan konservasi sumberdaya hayati laut dan pesisir di Indonesia." Jurnal biologi papua 3.1, 2011.

[7] Zeppelin, Daniela, et al. "Characteristics of meiofauna in extreme marine ecosystems: a review." Marine Biodiversity 48.1. 35-71, 2018.

[8] Unwin, Simon. Metaphor: an exploration of the metaphorical dimensions and potential of architecture. Routledge, 2019.

[9] Devadiga, Nitish M. "Tailoring architecture-centric design method with rapid prototyping." 2017 2nd International Conference on Communication and Electronics Systems (ICCES). IEEE, 2017.

[10] Jerobisonif, Aplimon, Ariency KA Manu, and Debri A. Amabi. "Konsep dan Metode Desain Arsitektur Bernard Tschumi." GEWANG: Gerbang Wacana dan Rancang Arsitektur 1.1, 2019.

[11] Lucas, Ray. Research methods for architecture. London: Laurence King Publishing, 2016.

[12] Lindarto D, F Eddy, and Harisdani DDReading the meaning of the shophouses façade in Dr. Mansur street corridor at Medan City. IOP Conference Series: Materials Science and Engineering, 2020.

[13] Park, Choon-Sik, and Kwang-Min Jung. "A Study on the Behavior Characteristics of Large Deep Foundations." Journal of the Korean Geosynthetics Society, 2020.

[14] Kurata, Takashi, and Takeo Haijima. "Space-frame Structure with Steel Forging Connections." Proceedings of IASS Annual Symposia. Vol. 2016. No. 6. International Association for Shell and Spatial Structures (IASS), 2016.

[15] Krisnayanti, Denik Sri, I. Made Udiana, and Henry JefrisonBenu. "Studi Perencanaan Pengembangan Penyediaan Air Bersih." JurnalTeknikSipil 2.1. 71-86, 2013. 
[16] Indonesia, Standar Nasional. Tata cara perencanaan sistem plambing. SNI 03-70652005, 2005. 